University of Michigan Law School

University of Michigan Law School Scholarship Repository

\title{
Dignity as Perception: Recognition of the Human Individual and the Individual Animal in Legal Thought
}

Joseph Vining

University of Michigan Law School, jvining@umich.edu

Available at: https://repository.law.umich.edu/book_chapters/111

Follow this and additional works at: https://repository.law.umich.edu/book_chapters

Part of the Animal Law Commons, Law and Philosophy Commons, and the Natural Law Commons

\section{Publication Information \& Recommended Citation}

Vining, Joseph. "Dignity as Perception: Recognition of the Human Individual and the Individual Animal in Legal Thought." In Understanding Human Dignity, edited by C. McCrudden, 573-90. Proceedings of the British Academy, 192. Oxford: Oxford University Press, 2013.

This Book Chapter is brought to you for free and open access by the Faculty Scholarship at University of Michigan Law School Scholarship Repository. It has been accepted for inclusion in Book Chapters by an authorized administrator of University of Michigan Law School Scholarship Repository. For more information, please contact mlaw.repository@umich.edu. 


\title{
Dignity as Perception: Recognition of the Human Individual and the Individual Animal in Legal Thought
}

\author{
Joseph Vining ${ }^{1}$
}

\section{Human dignity and forms of thought}

'TO THEIR MURDERERS THESE wretched people were not individuals at all. They came in wholesale lots and were treated worse than animals.' This was Telford Taylor, beginning the presentation of the 'Medical Case' at the Nuremberg Trials after the Second World War. ${ }^{2}$ The 'Medical Case' was not about genocide or war or the conduct of war. It was about experimentation on human beings; and it was this trial that produced the 'Nuremberg Code', the first control of such treatment of human beings by one another.

The word 'individual' came naturally to Taylor the lawyer as a starting point, and with it the contrast with animals. The connection between what kind of treatment these units of flesh and blood might receive, and whether they were individuals 'at all', came naturally to him too.

Taylor's opening at Nuremberg echoed the Nazi representative Joseph Goebbels' explanation in 1938 of German programmes of eugenic sterilization and euthanasia, themselves experiments. 'Our starting point is not the individual', Goebbels said. ${ }^{3} \mathrm{He}$ knew that this was the critical point in thought and then action, and he knew just what Taylor meant later by 'individual'.

\footnotetext{
${ }^{1}$ In this chapter I have drawn particularly on material in my Giannella Memorial Lecture, 'The mystery of the individual in modern law', at the Villanova University School of Law, Villanova Law Review 52 (2007), 1. I am indebted to James Boyd White and Christopher McCrudden for their detailed and helpful comments.

${ }^{2}$ Trials of War Criminals before the Nuremberg Military Tribunals under Control Council Law No. 10, October 1946-April 1949: The Medical Case, vol. 1 (Washington DC, US Government Printing Office), $27-8$.

${ }^{3}$ US Holocaust Memorial Museum, Deadly Medicine: Creating the Master Race (Chapel Hill, University of North Carolina Press, 2004), 8, citing Michael Burleigh and Wolfgang Wippermann, The Racial State: Germany 1933-1945 (Cambridge, Cambridge University Press, 1991), 69).
} 
With an inversion of a biblical passage that would be well known, Goebbels made explicit the implication of not starting with the individual: "[A]nd we do not subscribe', he said, 'to the view that one should feed the hungry, give drink to the thirsty or clothe the naked ... Our objectives are entirely different: We must have a healthy people in order to prevail in the world. ${ }^{4}$

We know the word 'individual' in Taylor's reference, or in Joseph Goebbels', is not referring merely to a unit, something discrete, an atom, a particle. Moving from units separate but interchangeable to the particulars of the experienced world that are each and always unique does not take us to the individual either. It takes us only to the little pebble or the rusting old car which there is nothing in the universe exactly like. The uniqueness of a living thing is just that, of pebble or rusty car, if it is only the product of those familiar elements of genetic nature and environmental nurture, the two poles of modern inquiry typically presented as exhausting the sources of living particularity. Biological parlance has a special name for that product, the phenotype, which is the current state of the mutual interaction of internal system and external system. Seeing the individual is looking in reality to something else besides, a third element.

What did the twentieth century threaten in the deepest way? What were those who eventually prevailed at such staggering cost fighting to protect? What was the great twentieth-century struggle about? The individual, and spirit itself, seen in us in being seen as an individual. The individual and spirit: they are linked, and their absence together defines the world of those two books emblematic of what the twentieth century might have brought, $1984^{5}$ and Brave New World. ${ }^{6}$

The home in the secular world for both these, the individual and spirit, is the legal mind and the legal form of thought. Both these connect law with religious sensibility and its work in us and in the world - the sensibility that the human, the human at least, if not also the sentience of other creatures, is spoken to and touched from beyond the world of the here and now. And it is the legal mind, rooted in and the possession of people in circles out and out from those professionally involved with it, that can protect humanity and the rest of the sentient world from reliving the twentieth century in the twenty-first.

The presence of the individual in modern law runs counter to the thrust of what are called 'modern' efforts to understand the world. The individual

\footnotetext{
' US Holocaust Memorial Museum, Deadly Medicine.

'George Orwell, 1984 (London, Secker \& Warburg, 1949).

'Aldous Huxley, Brave New World (London, Chatto \& Windus, 1932).
} 
is associated with openness, each individual new and a new source of understanding by others of the world, 'world without end', as the phrase goes; while modern thought presses towards finality of understanding, "theories of everything', 'final theories'. The individual human being's use of language is a source of newness and meaning, with translation of it on a presupposition of identity despite difference--more than presupposition, a sense of identitythat makes each of us a gift to the other. ${ }^{7}$

The individual is the carrier of creativity in the actual world. Creativity comes into the world despite views of the world, voiced of course by individuals, that have no place for creativity, in which everything in the world, and all thought itself, is the product of units of some sort operating by rules of some sort, Newtonian or post-Newtonian. The modern future, it is said, must be in principle predictable as the product of what has gone before, probabilistically or otherwise, even if it cannot in fact be predicted because of non-computability or some other inadequacy in our technical equipment. There simply is no creative force operating at any level to point to or produce what comes in the world unfolding before us. But-we see it every day-with each of us there comes into being a whole world.

\section{Individual animals}

The recognition of individuality in animals illustrates what perception of the human individual does in thought and means in practice. Taylor spoke of the wretched in the laboratories at Dachau or Buchenwald as not individuals 'at all'. They were treated 'worse than animals', 'as less than beasts' ${ }^{8}$ Nearly fifty years later in the USA, it appeared that chimpanzees had not proved as suitable a model as expected for AIDS research, both in themselves and because of their expense- and also, interestingly, because of widespread and persistent opposition to their use. The question what to do with those that remained came to the National Research Council Committee on Long-Term Care of Chimpanzees, and eventually to the US Congress.

The minority statement of the National Research Council Committee took the view that euthanasia of some was 'an appropriate strategy for maximizing the quality of life of the remaining population while facilitating the continued

\footnotetext{
${ }^{7}$ For some exploration, on my part, of the connection between the individual and the meaning of language, see Joseph Vining, 'Fuller and language', in Willem J. Witteveen and Wibren van der Burg (eds), Rediscovering Fuller: Essays on Implicit Law and Institutional Design (Amsterdam, Amsterdam University Press, 1999), 453-78.

'Trials of War Criminals, 27-8.
} 
production of chimpanzees to fulfill critical needs in biomedical and behavioral research'. It observed, '[j] ust as the viability of the species rather than of individual animals is proposed as the primary motivation for management strategies in the zoo situation', here 'the long-term viability of the resource for addressing biomedical research needs should be the primary concern'. 9 The majority, however, observed that the 'phylogenetic status and psychological complexity of chimpanzees indicate that they should be accorded a special status with regard to euthanasia that might not apply to other research animals', and that while not "the moral equivalent" of humans ... they are more like humans than other laboratory species might be with respect to some features relevant to the question of euthanasia'. ${ }^{10}$

This led to a US Senate Report adopting the majority position and to the federal Chimpanzee Health Improvement, Maintenance, and Protection Act of $2000,{ }^{11}$ which set up a federal sanctuary for them, and provided not only that once in the sanctuary they could not be transferred out and any experimentation on them would be subject to limitations more stringent than those governing experimentation on human children, but, further, that 'none of the chimpanzees may be subjected to euthanasia, except as in the best interests of the chimpanzee involved' ${ }^{12}$

The 'best interests of the chimpanzee involved'. The animal emerges as an individual here, and, I may say, from time to time elsewhere in law even when the animal is phylogenetically 'below' the higher primates. The individual when recognized begins to block weighing of costs and benefits, justification by relative numbers, thinking in terms of systems and processes, 'at the start' to use Goebbels' phrase. ${ }^{13}$ It is this blockage, this shift in kind of thinking, that is signalled when we begin to speak of an individual 'right'.

The connection between recognition of a being (including a being that is human) as an individual, and the possession of a 'right', an 'individual' right, draws on the image of property, the castle or the cottage, security within it,

\footnotetext{
- Commission on Long-Term Care of Chimpanzees, Institute for Laboratory Animal Research, Commission on Life Sciences, and National Research Council, Chimpanzees in Research: Strategies for Their Ethical Care, Management, and Use (Washington DC, National Academies Press, 1997), 88, 92.

${ }^{10}$ Commission on Long-Term Care of Chimpanzees, Chimpanzees in Research, 38-9.

"Senate Report No. 106-494, p. 2 (2000); Chimpanzee Health Improvement, Maintenance, and Protection Act, Pub. L. No. 106-551, §481C(d)(2), 114 Stat. 2753 (2000).

${ }^{12}$ Chimpanzee Health Improvement, Maintenance, and Protection Act $\S 481 \mathrm{C}(\mathrm{d})(2)(\mathrm{I}), \S 481 \mathrm{C}(\mathrm{d})(3)$; Code of Federal Regulations Part 46-Protection of Human Subjects, Subpart D- Additional Protections for Children Involved as Subjects in Research', 45 Code of Federal Regulations 46.401-9. The protections for chimpanzees in sanctuary are both substantive and procedural. The ultimate protections for children are procedural only, coupled with a directive to be ethical.

${ }^{13}$ US Holocaust Memorial Museum, Deadly Medicine, 8.
} 
and dominion over it. A 'right' is said sometimes to dispose of other considerations. Those who work with legal argument and legal reasoning know that a right is not a thing, bundled or unbundled, that one holds in one's hand in advance of legal argument or a legal proceeding. Lawyers know that whether or not one will be 'found' to have a right is determined by argument on the merits in which public values are considered, 'weighed' we say, and the value reflected in the putative right-holder's argument may not outweigh the rest. But in some cases what is represented by the words 'individual right' is dispositive and holds back the arguments of others. No torture is an example, if the individual is a human being. ${ }^{14}$ No slavery-for instance under the Thirteenth Amendment of the United States Constitution-may be another, looked to recently when the US Patent Office declared unpatentable a proposed being that would be grown to maturity after blending human and chimpanzee genetic material. ${ }^{15}$ In Canada, under charters of rights, no absolute denial of medical care to a human being in a time of pain may be another ${ }^{16}$ No human experimentation without true consent may be gradually emerging as another, now two generations after Nuremberg ${ }^{17}$-Article 3(b) of the 2005 UNESCO Universal Declaration on Bioethics and Human Rights provides that '[ $t]$ he interests and welfare of the individual should have priority over the sole interest of science or society'. ${ }^{18}$

When this happens, in the case of an animal or a human being, understanding what is happening must involve shifting focus to the recognition of the individual. It is not the possession of a right but the effect of perceiving one as an individual that holds back the claims of the rest of the world. Nor is it suffering that does it. We use metaphors of quantity as we contemplate and speak of suffering as more or less, as acute, extreme, unbearable, or mild.

\footnotetext{
14 J. Herman Burgers and Hans Danelius, The United Nations Convention Against Torture (Dordrecht, Martinus Nijhoff, 1988), 114-19, 123-4.

15 Rick Weiss, 'U.S. denies patent for a too-human hybrid', Washington Post (13 February 2005), A03; Aaron Zitner, 'Patently provoking a debate', Los Angeles Times (12 May 2002), Al (discussing part-human, part-mouse hybrid); Consolidated Appropriations Act (United States), Pub. L. No. 108$99, \S 634,118$ Stat. 3,101 (2004) (providing that no funds could be 'used to issue patents on claims directed to or encompassing a human organism').

${ }^{16}$ Chaoulliv Quebec, 2005, 1 S.C.R. 791. Cf. Case C-372/04, The Queen, on the Application of Kronne Watts $v$ Bedford Primary Care Trust, Secretary of State for Health (European Court of Justice, 16 May 2006), http://curia.europa.ew/en/content/juris/index.htm (addressing issue in European Union).

${ }^{17}$ For example, Burton v Brooklyn Doctors Hospital, 452 N.Y.S.2d 875, 881 (N.Y. App. Div. 1982); In re Cincinnati Radiation Litigation, 874 F. Supp. 796, 819-22 (S.D. Ohio 1995). The various utilitarian justifications for dispensing with true consent, such as scientific knowledge, medical advance, or military effectiveness, were forcefully argued at Nuremberg, and are argued still.

18 General Conference of UNESCO, 33d Session, Universal Declaration on Bioethics and Human Rights, Article 3(2), 19 October 2005.
} 
Metaphors of quantity appear again when we detach suffering from individual experience and seem to aggregate it. In utilitarian reasoning, the amount of suffering of one would be put against the amount of suffering that could be prevented or alleviated for others alive or to be born. But on any supposed calculus of suffering, the suffering of one would be a drop in the oceans of the world's present suffering, human, animal, that is now connected with life and that only death fully eliminates, and not even a drop but barely an atom when piaced against the eons of suffering that might be alleviated or prevented in the future, human and animal. In fact, we can see that the suffering of one can be as great as the suffering of all the world, the point made in the proposed bargain for the happiness forever of all mankind in the passage preceding the Grand Inquisitor scene in The Brothers Karamazov ${ }^{19}$ and made, I think, at every celebration of the Eucharist. But in seeing that, we are seeing the individual.

We can foreground what it is, in law, to recognize an animal as an individual, by asking the kinds of questions we used to hear in the mid-twentieth century as we were contemplating 'nuclear winter'. Would the death of all human beings be a loss? I think we would say yes, and not that humanity's passing would merely be evolution at work. Would the death of a group of human beings, leaving behind a 'remaining population' that might benefit from resources freed up, be a loss? Again, we would say yes. Would the death of a single human being be a loss? Again, we would say yes, a loss not only to other individuals who knew or individually valued him or her but to the world, and we express that in so many ways, not least the real impossibility, the acknowledged fiction, of calculating a measurement or monetary value of a single human life so that human lives could conceivably come in Taylor's 'wholesale lots'. ${ }^{20}$

So, in the same vein, would the death of all animals, or all of a kind of animal-extinction we call it--be a loss? If we said yes, rather than that this is only evolution at work, I think our minds would most likely be focused on the ecological and the environmental, on systems that support the systems within us. But is the death of a single animal a loss to the world? To the extent an animal is an individual at all, we may begin to feel pressure within and pull from without to say yes, as we do contemplating the death of a single human being.

\footnotetext{
${ }^{19}$ Fyodor Dostoyevsky, The Brothers Karamazov, trans. Constance Gamett (New York, Vintage Press, 1955), 219.

${ }^{20}$ Trials of War Criminals, 27-8.
} 
The pressure and pull from recognition of the individual is there in the legal mind, and has its effect whether or not it holds back other concerns and claims in the definitive way it does when torture or slavery are proposed. It was natural to Taylor at Nuremberg to say 'not individuals at all' as he presented humans conceived as 'less than beasts'. ${ }^{21}$ There is a metaphorical 'degree' in 'at all'-and in 'pressure' or 'pull'. But what is happening is blunting, slowing, and interfering with thinking that is quantitative, as so much of our thought is and necessarily is, capturing in definitions, categorising, unitizing, systematizing, and calculating. Modern thought-your mind and minemoves quickly to systems, and to units that can fit into a system. The pressure recognition of the individual introduces is instead towards imaginative escapes, reconfigurations, compromises that are temporary, facing the tragic in tragic choices made, and moving into the world of remorse, forgiveness, and beginning again to which calculation is utterly foreign.

The effect is easily seen, familiar really, in criminal law both as formulated and as applied. Judges, prosecutors, juries, legislators all feel it. The classic holding back of what is proposed to be done to a human convict for purposes of general deterrence, the insistence that a criminal sanction be linked in some proportional way to the mind condemned, is a turning of decisional attention to the individual who is at the mercy of the decisionmaker. When we say the 'retributive' purpose of a criminal sanction limits its utilitarian use, it is this to which we are referring. Procedure and procedural choices are affected throughout criminal law, as are the placing and relative heaviness of burdens of proof. 'Strict' or 'vicarious' criminal liability introduced in the aptly named public policy offences, apparently eliminating any inquiry at all into the mind and particular situation of an individual before criminal condemnation, is demonstrably moulded into liability that is neither strict nor vicarious. The more serious the proposed suffering of the individual, the greater is insistence on such inquiry, constitutionally pushed by the very notion of 'law' in 'due process of law' and in the USA by the constitutional word 'cruel'.

Then, on the animal side: in criminal law, inquiry into the justification for the actions of human beings accused of the felony of animal cruelty is pulled and moulded by the suffering of animals without regard to number. Medical and scientific experimentation is institutionalized and regulated by statute. In the USA the legal mandate runs to federal mini-agencies called Institutional Animal Care and Use Committees, established to approve or disapprove research proposals and 'represent society's concerns regarding

Trials of War Criminals, 27-8 (emphasis added). 
the welfare of animal subjects'. ${ }^{22}$ It is a mandate to researchers as well, and it focuses on individual animals. The absolute number of animals suffering is to be reduced to the lowest number possible, not the percentage of the kind but the absolute number. Experimental technique and procedure are to be refined to lessen each animal's suffering. Then, as a training manual for members of the enforcement committees instructs, '[f]inally, there comes a point in a number of research studies in which further pain and suffering by the animal is unjustified, no matter how noble the cause. It is the [committee's] role to recognize when this point has come and end the research trial at this time. ${ }^{23}$

In Canadian and US trusts and estates law, an animal moves on its owner's death out from under the general law of property and into the world of wills acts and probate codes. There are now cases in which courts have voided an order put into a will to destroy an animal left behind, fashioning something like a temporary judicial sanctuary for it, when a challenge to the order as against basic legal values is brought by an executor or an intervenor or, indeed, by the state attorney general. ${ }^{24}$ The Uniform Trust Code in the USA now provides for trusts for an animal effective for its life, in which the animal is an equitable beneficiary, and persons interested in the animal's welfare are given standing to intervene and seek enforcement of the terms of the trust. ${ }^{25}$ Time and again attention is paid to the individual animal, quite apart from any ecological, environmental, or species-preservation concerns. It is recognized, it presses, as if in law it can look you directly in the eye.

Consideration of the individual animal can help us focus upon and titrate out, as it were, the third element to which I have referred. What evokes the human response of 'respect' is not entirely contained in what we call 'the

227 United States Code $\S \S 2132(n), 2143(b)(1)$ ('Animal Welfare Act' of 1966 as amended); Congressional Finding (4) for Pub. L. No. 99-198, §\$2142-6, 99 Stat. 1645 (1985).

${ }^{23}$ Sally $\mathrm{K}$. Wixson, 'The role of the IACUC in assessing and managing pain and distress in research animals', in M. Lawrence Podolsky and Victor S. Lukas (eds), The Care and Feeding of an IACUC: The Organization and Management of an Institutional Animal Care and Use Committee (Boca Raton, FL, CRC Press, 1999), 115, 117. The Animal Welfare Act itself now prohibits, for any animal it covers, surgery using paralytics without anesthetics. The prohibition is absolute, without regard to motive or context. 7 United States Code $\$ 2143(a)(3)(C)(i v)$ (1985).

${ }^{24}$ For example, Capers Estate, 340 D. and C.2d 121, 135-38 (Orphan's Court PA, 1964); In the Matter of the Estate of Clive Wishart, 129 N.B.R.(2d) 397, 401-2, 408-9, 412-24 (New Brunswick Court of Queen's Bench [Canada], 1992), reviewing both US and Canadian law. For discussion, see Sonia S. Waisman, Pamela D. Frasch and Bruce A. Wagman, Animal Law: Cases and Materials, 3rd edn (Durham, NC, Carolina Academic Press, 2006), 587-98.

${ }^{25}$ Uniform Trust Code (United States) $\$ 408$ (2005); Official Commentary to $\$ 408$ ("The concept of granting standing to a person with a demonstrated interest in the animal's welfare is derived from the Uniform Guardianship and Protective Proceedings Act, which allows a person interested in the welfare of a ward or protected person to file petitions on behalf of the ward or protected person'.) 
human'. 'The individual' is not merely an expression of human self-regard. Noting this can uncouple us somewhat from the growing question about what is human and what is not, being raised by experimental work with embryonic stem cells, genetic engineering, and the hybridization of human and animal systems. It can even buffer us from the impossible question of relative degrees of human-likeness in legal categorizations of animals based on likenesses between human and animal physical systems, which is cousin to the impossible question of degrees of perfection within humanness in current eugenic discussion of 'selection in' or 'termination' using the tools of reproductive technology.

\section{The individual and the person}

Consideration of the individual that is an animal also pulls us away from mistaking the recognition and experience of the individual for the experience of persons. An animal may be an individual but not a person. On the human side, a slave may be property, a thing bought and sold, flogged and kicked, not a citizen or a legal person, thought even to be 'not fully human', but a slave presses nonetheless for entry into the perceived world as an individual. ${ }^{26}$ To allude again to the biological manipulation that is now possible, the temporal line often drawn between using a developing human unit in scientific experimentation, and staying the hand at using it in experimentation, is the fourteenth day of embryonic development. ${ }^{27}$ One of the reasons advanced for that line is the possibility of twinning before fourteen days and the challenge it may pose to perception of an individual until that possibility is past. ${ }^{28}$ For many who would adopt that line, the individual after fourteen days is not yet a person. Then at the end of life, the person may fade away. The individual

\footnotetext{
${ }^{26}$ For a sweeping examination of the normality of slavery before the recent past, and of what is seen when a slave is seen, and for the history of the development of perception leading to a prohibition of slavery that is 'absolute', see John T. Noonan Jr, A Church that Can and Cannot Change: The Development of Catholic Moral Teaching (South Bend, IN, University of Notre Dame Press, 2005), 3-123. ${ }^{27}$ Human Fertilisation and Embryology Act 1990, chapter 37, §3(3), (4) (Great Britain); National Research Council and Institute of Medicine, Guidelines for Human Embryonic Stem Cell Research (Washington DC, National Academies Press, 2005), 57 (United States).

${ }^{28}$ National Institutes of Health, Report of the Human Embryo Research Panel, vol. 1 (Bethesda, MD, National Institutes of Health, 1994), 45-7, 65, 67; Anthony Kenny, 'Life stories: when an individual life begins-and the ethics of ending it', Times Literary Supplement (25 March 2005), 3, 4 (quoting from Parliamentary Debates, 6th Ser., vol. 73, 15 February 1985, 682, remarks to the House of Commons by Kenneth Clarke, Minister for Health in Great Britain). The fourteen-day point is also the point after which appear 'the precursors of the brain and central nervous system'. National Research Council and Institute of Medicine, Guidelines, 55.
} 
stays - whom you do not experiment on or 'harvest' from--though the person fades. The individual is centred on the flesh, though that is something with which we do struggle, the continuing challenge of gnosticism in Christianity being only a more than usually clear example of struggle with it. ${ }^{29}$

Questions about how to use the terms 'individual' and 'person' are unsettled, but the terms as used do reflect an underlying sense of the difference between a person and an individual, indeed the difference between a person centred on an individual's body and the individual enfleshed there. ${ }^{30}$ A person, both in mundane or ordinary or daily or unself-conscious talk, and in the considered language of law, may be enfleshed. But a person need not be enfleshed and can speak through one or another individual. We can and do take on various legal identities without losing our individuality: they are not identities all our own. Persons join us together, and the standard assumption, that one can always be challenged when one speaks on behalf of a person who is not an individual, is evidence of such joining rather than separation. Identification with persons who are not individuals is what links us, in a real way, to future individuals beyond our span of life, even the distant future, with responsibility to them and hope for them. It is what links us, in obligation and gratitude, to individuals before our individual time, indeed what makes the past even relevant and interesting to us so that we are willing to spend precious individual time, the most wasting resource there is, working to determine what is authentic in our understanding of the past, and what is unreal.

As for the 'individual person', this is mutually developed in our conscious and unconscious understanding and experience over time. Other individuals continually sift and sort through what an individual says and does as an individual, identifying it with him or her as a person who exists over time, or putting it aside as mistake or inauthentic. We do the same with ourselves, doubting or trusting, persuading ourselves and believing. We sit in judgment on what we ourselves say and do.

The person perceived or heard is 'half-created' over time, real and alive to us because of our work, something of our own. The individual is always in the present. If time moves or if one moves through time, the individual is always with us. Anything said is always in the past, immediately so, evidence with which we work, but evidence only, not the same as what it is evidence

\footnotetext{
${ }^{29}$ Philip J. Lee, Against the Protestant Gnostics (New York, Oxford University Press, 1993); Walter Brueggemann, Praying the Psalms, 2nd edn (Eugene, OR, Cascade Books, 2007).

${ }^{30}$ I first worked on these problems, against the background of twentieth-century developments in 'standing', in Joseph Vining, Legal Identity: The Coming of Age of Public Law (New Haven, Yale University Press, 1978), 2-3, 6-7, 145-8, 179-81.
} 
of. The individual here and now is silent and lives with us in silence. As 'starting point', the individual always remains central. The person prevents the individual as starting point, this ongoing centrality, from ending in radical ignorance and isolation, solipsism and relativism. ${ }^{31}$

\section{Articulating perception}

But again, the third element, beyond systems internal and external, is what gives the individual its distinctive force in perception and action. This is what so demands to be fitted into our ongoing effort to put together the bits and pieces of our experience into a coherence that does not close the eyes to any of it. Without this third element, the individual's place in the worlds of other individuals would not be begun to be understood. Even if there is no real possibility - precisely because of the recognition of the individual — of anyone's tying up understanding of individuality into a finished package by the end of his or her life in the world, still our trying to articulate the perception on which we act can serve a purpose. It helps each of us in opening a door, moving to the side of systems in general, and stepping once more into the parts of the mind where quantification and calculation lose purchase.

Some might reach for the term used in professional philosophy, 'agency', to refer to this third element. But agency is too pale and neutral a term to evoke the force that recognition of the individual has, and this is because agency in its connotations remains attached to its origins in philosophic discussion and to language there that speaks of properties of units and emergent properties of systems of units, envisioning capturing all parts of experience, unitizing them so that they can be put in classes and groups of the same, and then manipulating them in ways logical or otherwise-rather than listening to them. Agents need not call as individuals do, appeal, stop, reveal as individuals do. Agency tames experience.

What to call the third element? The American pragmatist Richard Rorty summed up in the most wonderful way much of what we try to talk about in his response to a 1999 request for reflections upon the coming third millennium. He looked to 'accomplishing' a 'thorough-going secularization' before the fourth millennium. 'It will probably take', he said, 'at least a thousand years for human beings to give up the last remnants of the idea that they

31 'Half-create' is Wordsworth's - all the mighty world/Of eye and ear, both what they half-create, And what perceive'. William Wordsworth, 'Lines written a few miles above Tintern Abbey', in Stephen Gill (ed.), William Wordsworth: The Major Works (New York, Oxford University Press, 2000), 134. 
contain a spark of the divine: to see Beethoven and Jefferson as animals with extra neurons. ${ }^{32}$ He went on to speak of individuals in modern history who have 'unwittingly collaborated with each other ... to force us' to this conclusion about the nature of the sources of life and thought given us when we enter the world for our time in it. Rorty, so oblivious, it seems, to the phenomenon of human law and its recognitions, and so oblivious to what might be his own commitment to law's recognitions, and certainly his dependence on them in his life taken as a whole, calls the third element a 'spark of the divine' in denying it to both human and animal.

We have called the third element spirit here, rather than spark of the divine. Sparks go out, spirit continues. Sparks are units, spirit is not capturable. And it is because spirit is not capturable and is not predictable, ahd takes form in the human world in language the meaning of which is the meaning of its utterer and itself irreducible to any system, that spirit stands against the full thrust of thought that is distinctively twentieth century.

Not against thought of a religious kind, that continued through the century, not against legal thought, that has if anything flourished ${ }^{33}$ and become more central to human life as the number of human individuals has increased, and not against 'ordinary' thought of 'ordinary' individuals: spirit stands against thought that, because in its own terms it has no place for spirit, would squeeze spirit out from thought itself, against elite, informed thought that views success in manipulating the systems of the world to human ends as authority to teach the nature of the world as a whole. Distinctively twentieth-century thought is cosmological, agitatedly and aggressively so, and thus for many, not most but many, one aspect of the mystery of the individual in modern law is the individual being there at all after the twentieth century.

Full recognition of the individual human being may be described, and I think in a way not inconsistent with spirit being the third element, as accepting into one's world something analogous to the acceptance of the Big Bang into physics and into contemplation of the physical world. The individual is a singularity, a word nicely taken over by physicists from their own experience of being individuals-not a unit playing a part in the working of rules and quantities governed by rules. Each individual has a view of the reality of the world, the cosmos itself, that cannot be different from his or her view. One

\footnotetext{
${ }^{32}$ Richard Rorty, 'International books of the year-and the millennium', Times Literary Supplement (2 December 1999), 11.

${ }^{33}$ Steven D. Smith, Law's Quandary (Cambridge, MA, Harvard University Press, 2004). See Steven D. Smith, The Disenchantment of Secular Discourse (Cambridge, MA, Harvard University Press, 2010), 205-10, for further discussion of 'spirit' as used here.
} 
cannot say, 'I see the world in this way or see this in the world, but what I see is mistaken or an illusion.' One sees it the way one sees it. One can struggle with doubt and be open to change if open-minded and working with perceptions that themselves open out into the new and surprising. But one cannot truthfully say to another, 'The way you see the world is true, not the way I see the world.' Even if one hears oneself saying such a thing, the world remains the way one sees it, and another individual, who is only one, trying to dismiss it with the word 'solipsism', is merely denying that one is an individual like himself or herself.

When individuals are recognized by one another they acknowledge this sense on the part of each that each is at the centre of the world. The 'public' value of an individual life is bedrock-natural rather than a mysterious anomaly. 'Not for all the world', we say, and thought of 'all the world' and reference to 'all the world' is a quite understandable and common response to a proposal that something be done to an individual, a meaningful response, not hyperbole or nonsense. It is this ontological or cosmological sense, not of the smallness of the individual among the billions but of the largeness of the individual up to the level of the largeness of the world itself, that lies behind the blocking or blunting or continuous creative compromise with the kind of thinking, often called rational, that must work with fungible units. Since each of us is an individual, a cosmology that has a place for us will always be truer, or closer to truth, or have a greater claim to truth, than any cosmology that does not.

All this comes before and is not supplanted by the joining of individuals in persons and in the experience of living value. The first question of understanding each of us faces is not how can I be an individual or how could there possibly be an individual, but how can there be more than individuals, as there is, and how, in what can only be continuous acts of generosity, do we each see we are one among many?

However paradoxical such a sense of reality or such a cosmology may appear to be, and whatever the way it differs from consistently radical subjectivity on the one hand and consistently impersonal objectivity on the other, this is the sense of reality displayed to each of us individuals in the practice of law, expressed by law, making law possible, underlying what lawyers do. As Stephen R. L. Clark says so nicely of objectifying visions:

Fortunately-or providentially-our own sense of self, and our sense of significant others as individual selves, keeps breaking in. Our attention is always being drawn to individuals as something more than episodes or anecdotes within a single story. Instead of one world, there are, in a way, very many 
though each unitary world experiences itself as a fragment or an echo of the wider realm. ${ }^{34}$

Trinitarian Christianity has its words for this, and in its ecumenical reach seeks to understand the words for it in other enduring religious teachings. It is an ontology that, in addition to recognizing the world of each individual, recognizes faith in a reality beyond the worlds of each individual, which each of us is a new window on and from and for which each of us is a voice when we are, as we say, 'really' ourselves, authentic, not pretending, not false- a reality in which move the persons who join us and who are halfcreated by us all, but only half-created-a reality on which our individual action, each of us one among the billions, may have a causal effect neither we nor anyone else can trace.

But all this, internal system, external system, the third element that moves a unique unit to individuality, the individual person and the person we halfcreate-all can be put aside, and still the individual remains. Happily or unhappily, anything I or anyone may say in description of the individual, or of the place of the individual in thought, is soft when it comes up against the hard reality of the individual. The world just is as you see it and not otherwise. When you speak about anything (including about the individual), you just are only one speaking. I am and you are prior to our understanding. The past does not produce us - we come before the past. The existence, nature, and effects of the past are matters for our individual judgment or persuasion throughout our lives. Whatever may be thought generally of creation, we each are created, for there is no other language of understanding that begins to reach us as individuals. The current language of emergent properties or of complex adaptive systems certainly does not.

\section{Imaging dignity}

Is spirit what is recognized in an animal also? Is it spirit or an analogue that should be given a different name? The third element that moves an animal to individuality, with effects on human action similar to those implied whenever we speak of human dignity, may not be the same as the third element in the human. But as we have noted, the line between what is human and what is not may also be less and less secure as experimentation in genetics proceeds. Depending upon how strong in our own minds the connection between genetic

\footnotetext{
${ }^{34}$ Stephen R. L. Clark, Biology and Christian Ethics (Cambridge, Cambridge University Press, 2000), 315-16. Clark speaks of this breaking in as a 'spiritual tension' that 'is echoed in the biological'
} 
patterns and being human is, the phrase 'dignity simply by virtue of being a human being' may lose some of its ontological support and usefulness as an articulation of perception. Dignity can in fact already be found used in various legal contexts in connection with an animal ${ }^{35}$ - again, an animal and indeed a human being need not be a 'legal person' to be seen to be an individual.

Currently, much of what is perceived and seeks expression clusters around an animal's sentience, which is a legal term as much as it is a term in ordinary speech or in scientific investigation, ${ }^{36}$ and which doubles as expression of a line between animals that are seen as individuals and animals that are not. The relation between an animal's sentience and our spirit remains to be seen. We have only begun to open our eyes to the creatures around us.

A book I published several years ago had the title The Song Sparrow and the Child, ${ }^{37}$ with Claims of Science and Humanity as its subtitle. I contrasted the song sparrow with the child throughout, and then at the end touched on the question how great the difference really was and how long the difference will continue in our perception, thought, and action.

Once, while I was working on the book, I opened the US National Science Foundation's webpage setting out the call of scientific work, and there a song sparrow was on the screen, the first thing seen, with a reference to investigation of its neurobiological mechanisms. ${ }^{38}$ Some of the methods of investigation are brutal. What is done to a song sparrow would not be done to a child today - though the twentieth century witnessed such things done to children where the individual was obscured from view. Song sparrows are of

\footnotetext{
${ }^{35}$ Christopher McCrudden, 'Human dignity and judicial interpretation of human rights', European Journal of International Law 19 (2008), 708-9 (legal use of 'dignity' also with reference to animals). ${ }^{36}$ Maine Revised Statute Annotated title $7 \$ 3907$ (2001) (United States) ("'Animal" means every living, sentient creature not a human being.'); Treaty of Amsterdam amending the Treaty on European Union, the Treaties establishing the European Communities, and certain related acts: Protocol on protection and welfare of animals annexed to the Treaty of the European Community Protocol, Official Journal C340, 10/11/1997, 0110 ('The high contracting parties, desiring to ensure improved protection and respect for the welfare of animals as sentient beings, have agreed ...'). See Simon Conway Morris, Life's Solution (Cambridge, Cambridge University Press, 2003), a detailed discussion of scientific contributions to recognition of 'sentience' in animals; Alasdair MacIntyre, Dependent Rational Animals: Why Human Beings Need the Virtues (Chicago, Open Court, 2001), for an introduction to work in philosophy on the human and the animal that seeks to take into account these contributions, and individuality; Philip Low et al., The Cambridge Declaration on Consciousness, Francis Crick Memorial Conference (7 July 2012), http://fcmconference.org/img/Cambridge DeclarationOnConsciousness.pdf, on consciousness in animals; Barbara Smuts, 'Reflections', in J. M. Coetzee, The Lives of Animals (Princeton, NJ, Princeton University Press, 1999), 107-22, on relationships between individual human beings and individual animals, and on human-animal intersubjectivity.

${ }^{37}$ Joseph Vining, The Song Sparrow and the Child: Claims of Science and Humanity (Notre Dame, IN, Notre Dame University Press, 2004).

${ }^{38}$ National Science Foundation (United States), http://www.nsf.gov/od/pa/news/publicat/frontier/496/4sparrow.htm.
} 
particular interest to science, in part because a young song sparrow comes to sing a song that is special not just to its kind but to its individual throat and tongue-rather like the language of each of us.

I left the song sparrow to do its own work in the book, and did not spell out all the reasons for the choice of this creature rather than another to compare with a child. The song sparrow presented itself, not exotic, as common as a child. Its smallness sat with the smallness of the child. It was a dependable example because well known, like the standard laboratory mouse. There was the echo of its music.

But beyond this, I can suppose also some part of the attractiveness of the sparrow was its resonance with the comparison of human being and sparrow in the Gospel of Matthew. Emblems take flight from their origins. Forgetting its origin, $I$ had remembered the linkage in the form of a saying, 'Not a sparrow that falls but the eye of God is upon it', as in the refrain of the folk hymn that Mahalia Jackson and the blues singer Ethel Waters made a signature piece:

\footnotetext{
Why should I feel discouraged?

Why should the shadows come?

Why should my heart be lonely,

And long for heav'n and home?

I sing because I'm happy.

I sing because I'm free.

His eye is on the sparrow

And I know He watches me. ${ }^{39}$
}

If you go to the original in the Gospel, there will be found a comparison but not an equation. The actual words can be something of a surprise:

Are not two sparrows sold for a farthing? And one of them shall not fall on the ground without your Father. But the very hairs of your head are all numbered.

Fear ye not therefore, ye are of more value than many sparrows..$^{40}$

A line is drawn between the sparrow and the human being, at least to begin with (as in fact we do). The translators' farthing was the smallest coin, a quarter of a penny (and I recall that when I first saw a modern farthing, before decimalization, it was stamped with the image of a small bird). An a fortiori

\footnotetext{
${ }^{39}$ Civilla D. Martin and Charles H. Gabriel, His Eye is on the Sparrow (New York, Hope Publishing, 1905); Donna Britt, Amazingly, an American in Paris, Washington Post (7 March 1977), D1, D6; H. C. Boyer, 'Commentary', in Mahalia Jackson Gospels, Spirituals, and Hymns (Columbia 47084, 1991), 25; Laurraine Goreau, Just Mahalia, Baby (Waco, TX, Word Books, 1975), 181, 561; Ethel Waters with Charles Samuels, His Eye Is on the Sparrow: An Autobiography (Garden City, NY, Doubleday, 1951).

${ }^{40}$ Matthew 10:29-31 (King James).
} 
case builds on an image of the least. One sparrow was not worth even the smallest coin, in the market.

There is a further tension in the original. Every hair, every detail of life is significant; but there is more than a hint of determinism within a concern that would value us to the point of counting the hairs on our head. Again, like the line between sparrow and human being, we may think this not inappropriate as a reflection of our situation. The limit on what we can do and be, the fact that we are in systems, is part of what makes a scientist of all of us. Shakespeare plays on all this when Hamlet, going forward at the end and presenting us with decision at last, individual decision, famously remarks to Horatio, 'There's a special providence in the fall of a sparrow'.$^{41}$

But I think that as the image of the sparrow has come down, it has more and more represented one of no importance becoming of transcendent importance. It had appeared long before the Gospel comparison, in the Psalms- the altar of God a nesting place for the sparrow. ${ }^{42}$ Those who first sang 'His eye is on the sparrow' included many who knew what it was to be properties, fungible units in a system. Even the hard words of the Gospel shift to the single sparrow before returning to the many--there are 'two sparrows' bundled and sold for a farthing; it is 'one' who shall not fall. And the providence that Hamlet saw in the 'fall of a sparrow' was a special providence.

For me as for others, including the blues singers who returned to it so often, the image blends with the extraordinary statement of human equality and individual value further along in the Gospel of Matthew, ${ }^{43}$ which we have seen quoted already. It is a radical passage, of which I think the sparrow can be taken as an emblem. It carries on the oldest prophetic tradition and demands what seems impossible. It is still today a source of that side of the political spectrum we call individualistic. It is read around the globe, in unlikely places, by Christian and non-Christian, by scientist and non-scientist. And, it must be said, it can have been a source of the kind of totalitarianism that begins in an effort to realize it, before closing into the total. It addresses both action and inaction, commission and omission, doing with the fand and staying the hand, almost as if in anticipation of modern dilemmas. There is hierarchy in it, a 'least'. But then something happens, and happens to 'one'. The words are worth reading, for the first time, or again. They end:

I was an hungred, and ye gave me no meat: I was thirsty, and ye gave me no drink: I was a stranger, and ye took me not in: naked, and ye clothed me not:

\footnotetext{
${ }^{41}$ William Shakespeare, Hamlet 5:2 (New Haven, Yale University Press, 2003), 205, 217.

${ }^{42}$ Psalm 84 (King James).

${ }^{43}$ Matthew 25:42-5 (King James).
} 
sick, and in prison, and ye visited me not. Then shall they also answer him, saying, Lord, when saw we thee an hungred, or athirst, or a stranger, or naked, or sick, or in prison, and did not minister unto thee? Then shall he answer them, saying, Verily I say unto you, Inasmuch as ye did it not to one of the least of these, ye did it not to me.

One of no importance, the least, can become of transcendent importance. 